\title{
A STUDY OF GASTRIC ACIDITY IN INFANTS.
}

BY

LUCY WILLS, M.B., B.S.

Chemical Pathologist, Royal Free Hospital,

AND

DONALD PATERSON, M.B., M.R.C.P.

Physician, Westminster Hospital.

Physician to Out-Patients, Hospital for Sick Children, Great Ormond Street.

(From The Infants' Hospital, Westminster.)

The following study of gastric acidity in infants was undertaken to investigate possible differences of acidity in various clinical entities. A study of normal cases was made for purposes of comparison, not only with our own abnormal cases, but also with the cases recorded in the literature (Table I.). It was obvious that, for the completely normal infant under

TABLE I.

\begin{tabular}{|c|c|c|c|}
\hline Authority. & Type of Case. & Feed. & $\begin{array}{l}\text { Average Maximum } \\
\text { Gastric Acidity } \\
\text { expressed as pH. }\end{array}$ \\
\hline $\begin{array}{l}\text { Davidsohn } \\
\left(^{3}\right)\end{array}$ & $\begin{array}{l}\text { Infants under } \\
4 \text { months } \\
\text { Infints up to } 7 \\
\text { months } \\
\text { Infants over } 7 \\
\text { months }\end{array}$ & 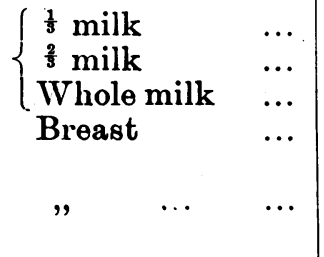 & $\begin{array}{l}5 \cdot 1 \\
4 \cdot 9 \\
4 \cdot 7-6 \cdot 2 \\
4 \cdot 48 \\
\\
2 \cdot 92\end{array}$ \\
\hline$\underset{(7)}{\text { Marriott }}$ & $\left.\begin{array}{l}\text { Normal Infants } \\
1-12 \text { months }\end{array}\right\}$ & $\begin{array}{l}\left\{\begin{array}{l}\text { Breast } \\
\text { Sweet cow's milk }\end{array}\right. \\
\left\{\begin{array}{l}\text { Breast } \ldots \\
\text { Sweet cow's milk }\end{array}\right.\end{array}$ & $\begin{array}{l}3 \cdot 75 \\
5 \cdot 3 \text { immediately } \\
4 \cdot 75 \text { after some } \\
\text { time on feed } \\
4 \cdot 75 \\
5 \cdot 35\end{array}$ \\
\hline $\left.\begin{array}{l}\text { Babbott } \\
\text { and Others } \\
\left({ }^{1}\right)\end{array}\right\}$ & $\left.\begin{array}{c}\text { Hospital cases not } \\
\text { seriously ill }\end{array}\right\}$ & $\left\{\begin{array}{c}\text { Test foed approxi- } \\
\text { mately skim milk }\end{array}\right\}$ & $3 \cdot 2-5 \cdot 0$ \\
\hline$\underset{(5)}{\text { Kronenberg }}$ & Normal Infants... & $\left\{\begin{array}{lr}\text { Breast } & \ldots \\
\text { Cow's milk } & \text { and } \\
\text { test feeds } & \ldots\end{array}\right.$ & $\begin{array}{l}5 \cdot 0 \\
4 \cdot 0\end{array}$ \\
\hline$\underset{\left({ }^{8}\right)}{\operatorname{Parsons}} \quad \cdots$ & Marasmic cases ... & $\left\{\begin{array}{c}\text { Artificial feeds } \\
\text { Fresh or dried } \\
\text { cow's milk }\end{array}\right\}$ & $\left\{\begin{array}{l}\text { Free hydrochloric } \\
\text { some time during } \\
\text { digestion }\end{array}\right.$ \\
\hline
\end{tabular}


7 months, our average figures of $\mathrm{pH} 2.70$ for breast fed children and $\mathrm{pH} 3.5$ for the artificially fed, indicate much higher acidities than those recorded by other writers. Davidsohn(3), Marriott(7), and Kronenberg(5) give figure:s ranging from $\mathrm{pH} 3.75$ to 5.0 for normal infants up to 7 months, which would correspond to lower average acidities. Davidsohn(3), for normal breast fed infants over 7 months old, finds an average acidity of $\mathrm{pH} .2 .92$, practically the same value as our figure for the same type under 7 months. Babbott and co-workers(1), working with a skim milk feed and using convalescent cases which were considered normal as far as their gastric function was concerned, found a wide range of acidity, from $\mathrm{pH} 3 \cdot 2$ to $5 \cdot 0$.

Further observations on underweight, but otherwise normal, infants indicated that, contrary to the usual teaching, given comparable cases, with the possible exception of the completely normal, the average maximum gastric acidity is the same, regardless of the nature of the feed.

These findings are set out in full below, together with a series of observations on sick infants.

Before discussing the methods used and the findings, a brief note on the terms used will perhaps be useful. The true acidity of a solution is the measure of the hydrogen $(\mathrm{H})$ ions present in that solution. For example, a $\mathrm{N} / 10$ solution of hydrochloric acid contains $1 / 10$ molecular weight of $\mathrm{HCl}$ in grammes dissolved in a litre and this $\mathrm{HCl}$ is $91 \%$ dissociated at this dilution: the hydrogen ion concentration is therefore $9.1 \times 10^{-2}$. To avoid the use of so many figures Sörenson introduced the exponent $\mathrm{pH}^{*}$, as the expression of the hydrogen ion concentration, or true acidity:--for a $\mathrm{N} / 10 \mathrm{HCl}$ solution $\mathrm{pH}$ equals $1 \cdot 04$. The disadvantage of the exponent $\mathrm{pH}$ is that as the acidity increases it becomes less and vice versa, e.g., a neutral solution has a $\mathrm{pH}$ of $7 \cdot 0$, figures below this $(\mathrm{pH} 2 \cdot 0)$ indicate acid solutions and figures above ( $\mathrm{pH}$ 8.0) alkaline ones. The exponent $\mathrm{pH}$ will be used throughout the following papers to express the true acidity of the solutions under consideration.

A "buffer" substance is one that allows the addition of an acid or alkali to a solution without an appreciable alteration in the reaction (acidity or alkalinity) of the solution. The protein of milk is such a substance; it, so to speak, " mops up " added acid, so that till sufficient acid has been added to saturate the buffer, there is only a slight increase in the acidity or hydrogen ion concentration of the solution.

The titratable acidity, determined with caustic soda, gives a measure of the total acidity, both free and combined. It is, therefore, an index of the acid excreted by the stomach.

The term "free hydrochloric acid" is used to denote the hydrochloric acid which is not linked to the " buffer substance ". of the stomach contents. but is present in the uncombined condition.

${ }^{*} \mathrm{pH}$ equals the logarithm to the base 10 of the concentration of $\mathrm{H}$ ions in grammes per litre, the negative sign being understood. 
METhods.

No definite test meals were given, but the stomach contents were removed and examined after the ordinary feed. A soft rubber catheter (Jacques) was passed, generally portions of the stomach contents were expelled through the tube; failing this, portions were removed by a syringe. There was generally no difficulty in obtaining samples, but if there was excessive salivation or retching samples were rejected.

Either the whole stomach content was removed or the fractional method of sampling was used. Babbott(1) and Davidsohn(3) have discussed the errors in these methods and, as in two samples taken immediately one after the other the differences in $\mathrm{pH}$ may be as great as 0.3 , it is essential, if the single sample method is used, to attempt to empty the stomach. In the fractional tests, this error is recognised. From a study of the curves of gastric acidity (see later), it was decided that, if single samples were to be used, they must be obtained at the height of digestion. In breast fed infants, this is at about one hour, and, in the artificially fed, at about two hours. When the children are ill, the maximum is generally somewhat delayed. Figures in the text refer to such samples.

The samples were strained immediately through gauze and then dialyzed through collodion sacs, according to the method of Levy, Rowntree and Marriott(6). The hydrogen ion concentration of dislysate was determined colorimetrically and expressed as $\mathrm{pH}$, the indicators used being thymol blue

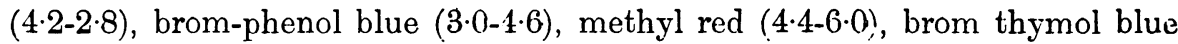
$(6 \cdot 0-7 \cdot 6)$. The indicators and standard solutions were made according to the directions given by Clark and $\mathrm{Lub}^{(2)}$ and were tested for us, by the hydrogen ion electrode method, by Dr. Jordon-Iloyd at the Iister Institute. Repeated estimations were satisfactory and the error for the whole method should not be more than + or -0.2 on the final $\mathrm{pH}$ reading.

The samples removed were also tested for free hydrochloric acid by Gunzberg's reagent, and, whenever enough was obtained, titrated with N/10 soda, phenolphthalein as indicator, to give the titratable acidity. Notes were made as to the presence or absence of curds and their size.

\section{RESULTS.}

Normal breast fed and artificially fed infants from one to nine months.

Ten children were studied in this group. They were normal, healthy infants with no discoverable defect or ailment, and all had excellent activity. None were attending the hospital, nor were they inmates of infants' home; They did not belong to the rery poor strata of society, but were clean, well cared for children. Six were breast fed, three were fed on cow's milí mixtures and one fed on a dried milk mixture. The stomach contents were examined by the fractional mothod and the results are shown in Table II. and Chart I. The average maximum acidity for the whole group was 
TABLE II.

NormaL ChILdRen.

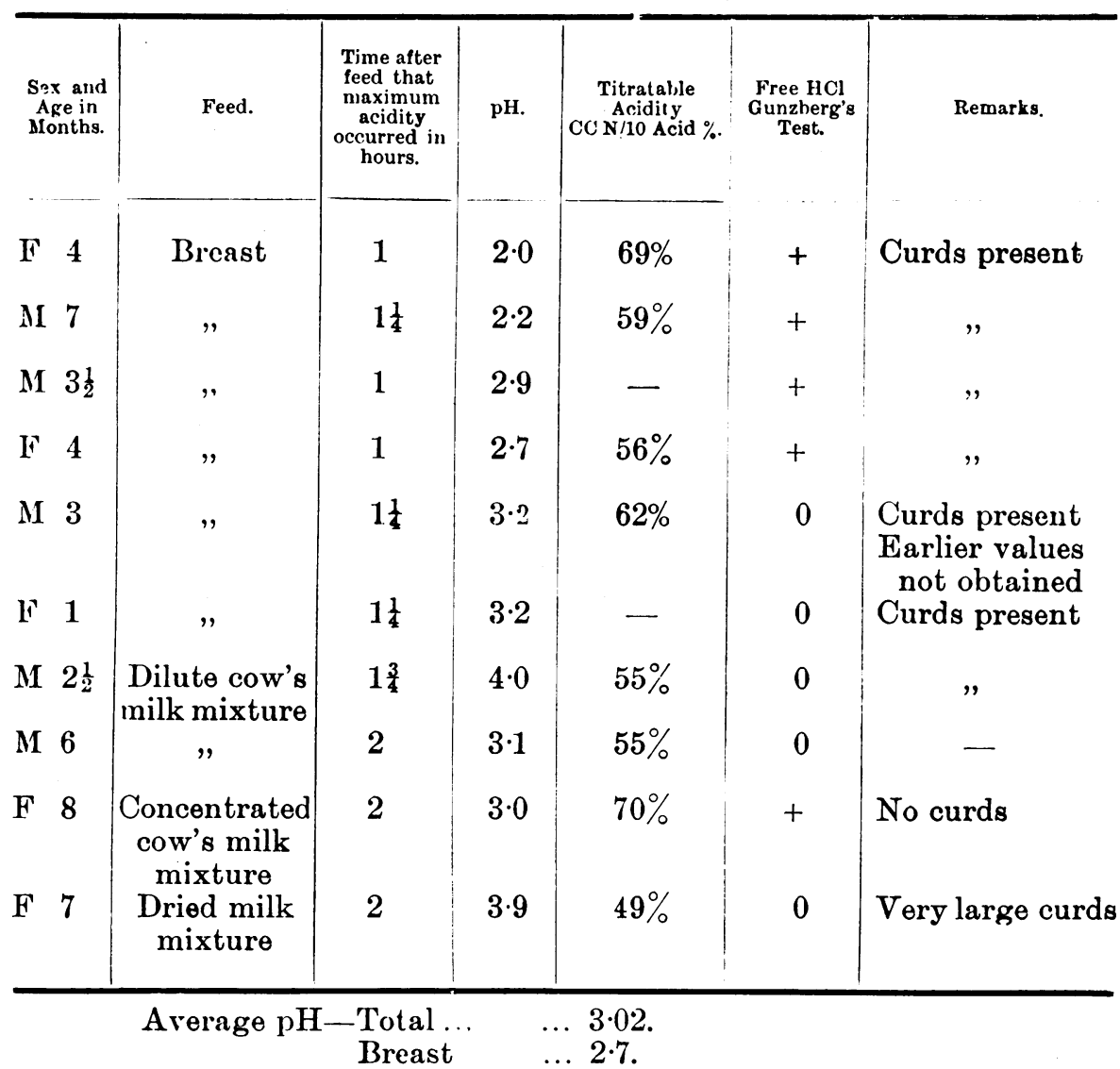

Artificially fed $3 \cdot 5$.

ChaRT I.

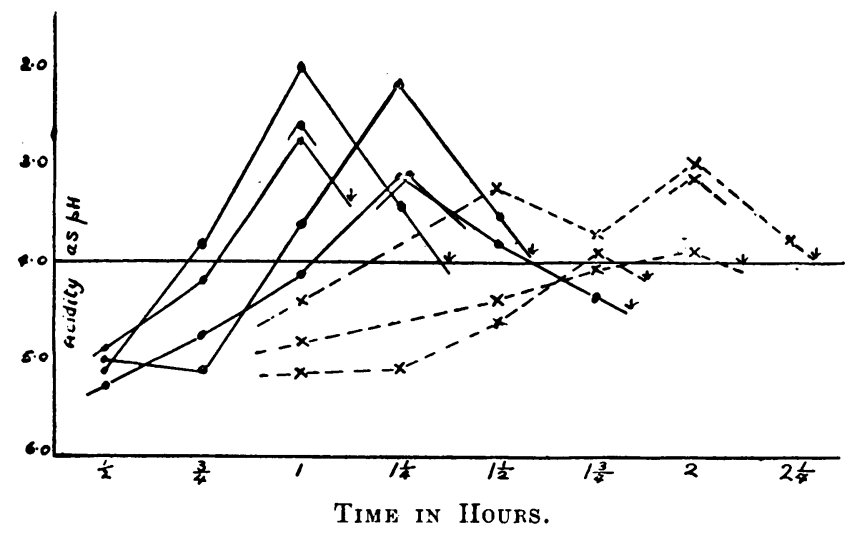

Curves o? gastric acidity in 10 : $c 1$ mal infants aged 1.9 montl.s

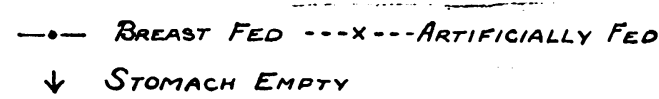


$\mathrm{pH} 3.02$ and for the six breast fed infants $\mathrm{pH} 2 \cdot 7$. The highest acidity, $\mathrm{pH} 2.0$, occurred in a breast fed child of 4 months one hour after feeding: this value did not represent pure gastric juice as curds were still present. In an infant of 1 month at $1 \frac{1}{1}$ hours after feeding, the $\mathrm{pH}$ of the gastric contents was $3 \cdot 2$, but as there was very little in the stomach and no curds, this figure probably represents the acidity of the gastric secretion itself. Free hydrochloric acid was present in the gastric contents of four out of the six breast fed infants at some time during digestion, but only in one case was it detected in the artificially fed children. A titratable acidity of $69 \% \mathrm{~N} / 10$ acid corresponded to a $\mathrm{pH}$ of 2.0 in a breast fed infant and to a $\mathrm{pH}$ of $3 \cdot 0$ in an artificially fed child, showing the difference in buffering of the two feeds. Chart I. demonstrates the high maximum, the rapid rise in acidity and the rapid emptying in the breast fed and the lowered flattened curve and delayed rise in the artificially fed. A study of more artificially fed infants would probably show a less marked difference. In this connection eight artificially fed patients that were diagnosed as normal(D.P.), though attending hospital, may be considered. The average maximum $\mathrm{pH}$ was $3 \cdot 5$, the same as that for the similar true normal, but one child aged 7 months on a drie: milk feed gave a maximum $\mathrm{pH}$ of $2 \cdot 5$, a value of the same order as those of the breast fed normals. These eight cases showed the same delay in attaining the maximum acidity as the other artificially fed cases.

The high true acidity values (low pH's) in the breast fed are such that peptic digestion would be active; in fact, the optimum for pepsin (about $\mathrm{pH} 2 \cdot 3$ ) was reached in two cases. The artificially fed infants also showed values in which peptic digestion would be appreciable, i.e., under $\mathrm{pH} 4 \cdot 0$.

Underweight children.

In this group 63 children were studied. It was impossible to do a fractional analysis on all of these patients, so, when this could not be done, samples were taken at approximately two hours in the artificially fed and at approximately one hour in the case of the breast fed, and the $\mathrm{pH}$ of these samples taken as representing the maximum acidity. From a study of the curves in Chart I., it will be seen that this method is only an approximate one, but it is one largely used by other workers and therefore yields comparable figures.

The infants selected, except for the fact that they were all under weight and many were not gaining well, might be regarded, from the point of view of gastric function, as normal.

Table III. gives the average findings for the whole of this group and for the different classes of feeds used. The ages varied from 3 weeks to 1 year. The average $\mathrm{pH}$ of the gastric contents at the height of digestion was 3.94 and the range of values found at this time 1.8 to 5.3. Free hydrochloric acid was found in $12 \%$ of the cases, but, as fractional analyses wcre the exception, this figure was almost certainly too low. The average figures for the different feeds are extremely near together, which is surprising, in view of the current teaching on the subje:t. 
TABLE III.

UNDERWEIGHT CHILDREN.

\begin{tabular}{|c|c|c|c|c|c|c|}
\hline $\begin{array}{c}\text { Number } \\
\text { of } \\
\text { Cases. }\end{array}$ & Nature of Feed. & $\begin{array}{c}\text { Age in } \\
\text { Months. }\end{array}$ & $\begin{array}{c}\text { Average } \\
\text { maxinumum } \\
\text { Acidity } \\
\text { as pH. }\end{array}$ & $\begin{array}{c}\text { Range of } \\
\text { maximum } \\
\text { Acidity }(\mathrm{pH}) .\end{array}$ & $\begin{array}{c}\text { Range of } \\
\text { maximum } \\
\text { Titratable } \\
\text { Acidity } \\
\text { CO N/10 Acid. }\end{array}$ & $\begin{array}{l}\text { Average maxinum } \\
\text { Titratable Acidity } \\
\text { OC N/10 Acid. }\end{array}$ \\
\hline 14 & Breast & $3-9$ & $4 \cdot 1$ & $2 \cdot 4-4 \cdot 7$ & $16-50 \%$ & $35 \%$ \\
\hline 13 & $\begin{array}{c}\text { Dilute cow's } \\
\text { milk } \\
\text { mixtures }\end{array}$ & $2-10$ & $3 \cdot 93$ & $2 \cdot 4-5 \cdot 0$ & $28-70 \%$ & $44 \%$ \\
\hline 8 & $\begin{array}{l}3 \text { parts or } \\
\text { more cow's } \\
\text { milk to } \\
1 \text { water }\end{array}$ & $3-12$ & $3 \cdot 87$ & $2 \cdot 6-4 \cdot 4$ & $36-71 \%$ & $55 \%$ \\
\hline 17 & $\begin{array}{l}\text { Dried milk } \\
\text { mixtures }\end{array}$ & $2-9$ & $3 \cdot 84$ & $1 \cdot 8-5 \cdot 3$ & $28-83 \%$ & $53 \%$ \\
\hline 52 & Mean & $\frac{3}{4}-12$ & $3 \cdot 94$ & $1 \cdot 8-5 \cdot 3$ & $16-83 \%$ & $47 \%$ \\
\hline
\end{tabular}

C'ases of persistent vomiting.

'I'his group consists of seven children who suffered from persistent and intractable vomiting. Two had diarrhœa as well, but in the remaining five cases this was not present. All were artificially fed. Table IV. shows

TABLE IV.

Cases of Persistent Vomiting.

\begin{tabular}{|c|c|c|c|c|c|c|}
\hline $\begin{array}{l}\text { Sex and } \\
\text { Age in } \\
\text { Months }\end{array}$ & Feed & $\begin{array}{l}\text { Time } \\
\text { after } \\
\text { Feed } \\
\text { in } \\
\text { hours }\end{array}$ & $\mathrm{pH}$. & \begin{tabular}{|c} 
Titra- \\
table \\
Acidity \\
cc N/10 \\
Acid
\end{tabular} & $\begin{array}{c}\text { Free } \\
\text { HCl } \\
\text { Gunz- } \\
\text { berg }\end{array}$ & Remarks \\
\hline \multirow{3}{*}{ F 2} & \multirow{3}{*}{$\begin{array}{l}\text { Dilute cow's milk } \\
\text { mixture }\end{array}$} & 2 & $2 \cdot 0$ & $88 \%$ & + & Curds present \\
\hline & & $2 \frac{1}{4}$ & $2 \cdot 0$ & $92 \%$ & + & \\
\hline & & 3 & $2 \cdot 0$ & - & + & , \\
\hline M 3 & Dried milk mixture & 2 & $2 \cdot 2$ & $92 \%$ & + & " \\
\hline F $3 \frac{1}{2}$ & & $2 \frac{1}{2}$ & $2 \cdot 9$ & - & + & No curds \\
\hline M 4 & $\begin{array}{l}\text { Dilute co:v's milk } \\
\text { mixture }\end{array}$ & 2 & $2 \cdot 4$ & - & + & Curds present \\
\hline$M$ & Nestlés $\quad \ldots \quad \ldots$ & $1 \frac{3}{4}$ & $3 \cdot 4$ & - & 0 & Very ill \\
\hline$F^{\prime} \quad 5 \frac{1}{2}$ & $\begin{array}{l}\text { Dilute cow's milk } \\
\text { mixture }\end{array}$ & 2 & $3 \cdot 2$ & $70 \%$ & + & Curds present \\
\hline IF 9 & Dried milk mixture & 2 & $3 \cdot 8$ & $68 \%$ & 0 & $"$ \\
\hline
\end{tabular}


the result of gastric analysis in these cases. The average acidity was $\mathrm{pH} 2 \cdot 4$, the value for titratable acidity ranged from 68 to $92 \% \mathrm{~N} / 10$ acid and free hydrochloric acid was present five times out of seven. The youngest child was 2 months old: gastric analyses wcre done on several occasions in this case and always gave the amazingly high acid values shown on Table IV.: at the end of three hours, curds were still present in the stomach, so that there was a markedly delayed emptying as well as a high acidity.

Ill children.

The next group consists of children suffering from acute infections and seriously ill. Thirty-two cases in all were studied, both by the fractional method and by the single estimation method; in all 108 estimations were made. Table $\mathrm{V}$. gives the range and average maximum findings in the group and the various types of cases studied.

TABLE V.

ILL CHILdRen.

\begin{tabular}{c|c|c|c|c|c|c}
\hline $\begin{array}{c}\text { Number } \\
\text { of } \\
\text { Cases. }\end{array}$ & Disease. & $\begin{array}{c}\text { Age in } \\
\text { Months }\end{array}$ & $\begin{array}{c}\text { Range of } \\
\text { maximum } \\
\text { Acidity } \\
\text { as pH. }\end{array}$ & $\begin{array}{c}\text { Average } \\
\text { maximum } \\
\text { Acidity } \\
\text { as pH. }\end{array}$ & $\begin{array}{c}\text { Range of } \\
\text { Titratable } \\
\text { Acidity } \\
\text { CCN/10 Acid. }\end{array}$ & $\begin{array}{c}\text { Free HCl } \\
\text { Gunzberg } \\
\%\end{array}$ \\
\hline 15 & $\begin{array}{c}\text { Infections } \\
\text { Bronchitis } \\
\text { Middle ear, etc. }\end{array}$ & $2-9$ & $6 \cdot 6-3 \cdot 3$ & $4 \cdot 92$ & $21-64 \%$ & $0 \%$ \\
11 & $\begin{array}{c}\text { Extreme } \\
\text { Marasmus }\end{array}$ & $2-9$ & $5 \cdot 9-3 \cdot 3$ & $4 \cdot 86$ & $25-80 \%$ & $0 \%$ \\
5 & $\begin{array}{c}\text { Eczema severe } \\
1\end{array}$ & $1 \frac{1}{2}-7$ & $6 \cdot 7-4 \cdot 0$ & $5 \cdot 14$ & $12-45 \%$ & $0 \%$ \\
\hline 32 & $\begin{array}{c}\text { Arsenical } \\
\text { Dermatitis }\end{array}$ & 10 & - & $3 \cdot 4$ & $68 \%$ & $0 \%$ \\
\hline
\end{tabular}

A study of the curves obtained by fractional analysis is of special interest, especially when compared with the curves obtained from normal infants on the same feed. Charts II., III., IV. and V., give the results. The most striking difference is the marked lowering of the curve of gastric acidity (expressed as $\mathrm{pH}$ ) in the sick children; this lowering is shown relative to every type of feed and is as striking in the breast fed children as in the artificially fed. The curves in the sick cases are also flatter than the corresponding normal curves. In Chart III., a composite curve from the values obtained in under-nourished infants fed on concentrated cow's milk mixtures is shown instead of a curve of normal values, as it so happened that in our series of normal infants none were fed on such concentrated mixtures. The titratable acidity is correspondingly low in these sick cases and naturally gives the same flat curves.

Gastric juice.

Before discussing the above results, it is of interest to consider the question of the gastric secretion itself. It was not possible to obtain samples of resting juice, but in certain cases samples were obtained, generally more 
than $2 \frac{1}{2}$ hours after feeding, in which there were no curds, and which probably approximated to gastric juice, though whether a psychic secretion or the result of the stimulation of the previous feed cannot be said. The figures compare with Babbott's(1) figure of 3.3 . which was obtained by lavage of the stomach. The average pH. of such samples was 3.07 and free hydrochloric acid was present in practically every case. In sick children, such curd-free gastric juice was only obtained twice, when the $\mathrm{pH}$ 's were respectively 6.7 and 4.0 , but in both cases the sample withdrawn consisted largely of mucus.

\section{Composite Curves of Gastric Acidity in Normal ayd Ill Infants-All Cases}

Chart II.-Breast

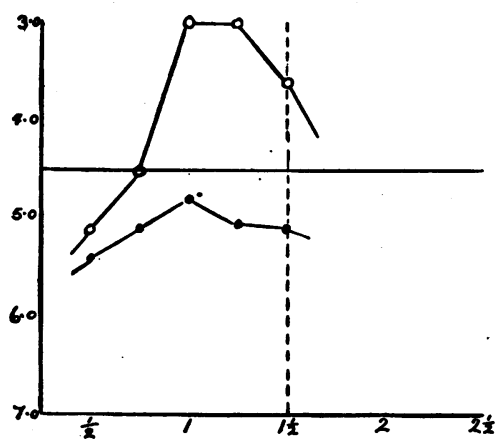

Chart IV.-Dilute Cow's Milk Mixtures

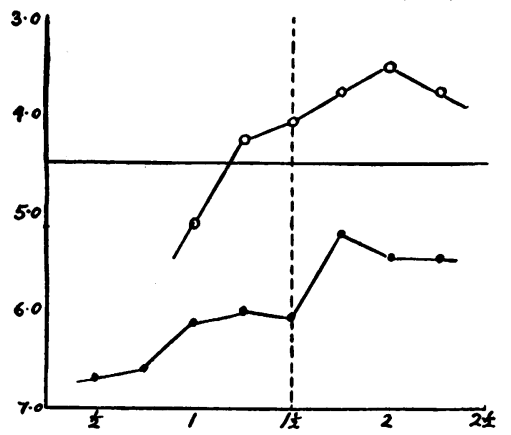

Chart III.-Concentrated Cow's Milk Mixtures

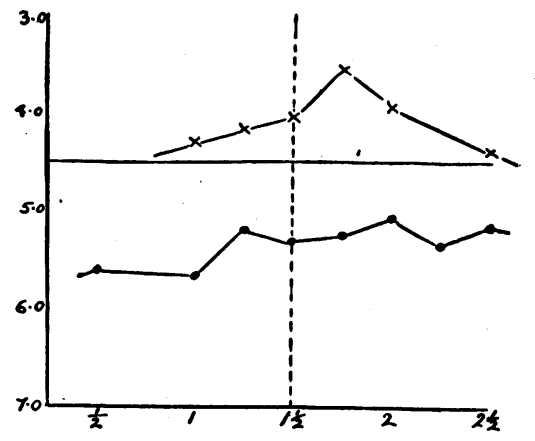

Chart V.-Dried Milk Mixtures

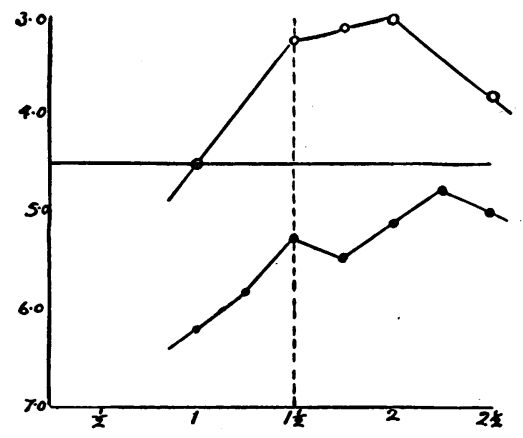

-o- normal Cases - - - Sick Cases - - - Underiveight Cases

Discussion of Results.

Sampling.

To the two methods of sampling used in this work there are obvious limitations. The object of a fractional gastric analysis is to follow the changes in the stomach during digestion, but the fact of removing samples is in itself a disturbing factor. Again in single samples, taken at any definite 
time, it is impossible to judge the stage of digestion reached. A study of the curves in Charts I. to V. shows that samples withdrawn at one hour in the breast fed normal infant will represent the condition at the height of digestion, whereas this would not be the case in the artificially fed A slight shift in time may make a great difference in value and also the error in sampling, according to Babbott(1) and Davidsohn(3), may be as great as $\mathrm{pH} 0.3$. It is therefore necessary when using single samples to have a large number of cases from which to draw conclusions. Further, different workers have used different methods, therefore it is important before comparing their results to see that the samples under discussion are really comparable. Another cause of error in the samples rencoved is excessive salivation and also the swallowing of mucus. Davison(4) has shown the importance of these. In the cases recorded, those that had excessive salivation or nausea were excluded.

In the discussion of the fractional findings, the error in sampling is recognised, but, as the curres are remarkably similar and when repeated on the same case constant (Table VI.), they are of considerable interest and value.

TABLE VI.

Repeated Test Meals.

\begin{tabular}{|c|c|c|c|c|c|}
\hline \multirow[b]{2}{*}{ Case } & \multicolumn{5}{|c|}{$\frac{\mathrm{pH}}{\text { Time after feed in hours }}$} \\
\hline & $1 \frac{1}{4}$ & $1 \frac{1}{2}$ & $1 \frac{3}{4}$ & 2 & $2 \frac{1}{4}$ \\
\hline \multirow{3}{*}{1} & $4 \cdot 1$ & - & $3 \cdot 8$ & $4 \cdot 0$ & Einpty \\
\hline & $4 \cdot 2$ & $4 \cdot 4$ & $3 \cdot 8$ & Empty & - \\
\hline & - & $4 \cdot 4$ & $3 \cdot 8$ & $4 \cdot 1$ & Empty \\
\hline \multirow{2}{*}{2} & - & $4 \cdot 3$ & 3.9 & $4 \cdot 1$ & Empty \\
\hline & - & $4 \cdot 1$ & $4 \cdot 0$ & $4 \cdot 0$ & Empty \\
\hline
\end{tabular}

Parsons ${ }^{(8)}$ has pointed out that in the majority of his cases (marasmus) free hydrochloric acid occurred at some point in the curve. In our experience, to obtain such results it is necessary to take samples as near together as possible, as the rise and fall may be very rapid. 
Normal values.

The cases recorded as normals would, in the light of our work, appear rather as subnormals. Babbott and his co-workers(1) recognise that their cases are not completely well, but assume that the gastric function is not affected. The group of normal children in our series shows the difference between the really active healthy infant and these subnormal hospitalised cases. Especially is this remarkable in the breast fed infant, where the average maximum acidity figure is $\mathrm{pH} 2 \cdot 7$. Comparing this with Davidsohn's(3) figure for breast fed children over 7 months ( $\mathrm{pH} 2.92$ ). it is seen to agree closely, but the six cases studied by us were all under 8 months, one only was 7 months, the remaining five being aged $1,3,3 \frac{1}{2}, 4$ and 4 months respectively. The maximum in the child aged 1 month was $3 \cdot 2$, this probably representing pure gastric juice. The shape of the curves is also remarkable. The steep rise and rapid emptying should be particularly noted.

From a consideration of these figures it is obvious that there is a greater opportunity for peptic digestion in the healthy infant's stomach than is generally thought, since pepsin is half active at $\mathrm{pH} 4.0$ and fully active at $\mathrm{pH} 2 \cdot 3$, a value often reached in the breast fed infant. Further, in these normal breast fed cases, the stomach is empty at $1 \frac{1}{2}$ hours, so that on a three-hourly feed there is usually a resting period of $1 \frac{1}{2}$ hours before the next feed. The few normals on artificial feeds do not give such high curves, but they are too few to permit conclusions to be drawn from them. What should be remarked, however, is the delay in reaching the maximum.

The group of underweight children mentioned above corresponds to many of the normals of the literature, i.e., these are subnormal children. Our findings (Table III.) are somewhat higher than those of most other workers, though Marriott's(7) figure of $\mathrm{pH} 3.75$ for well breast fed children indicates a slightly higher average acidity. The fact that he obtained samples two hours after feeding in breast fed children suggests that these were not completely normal as in such the stomach would generally be empty at such a time (see Chart I.), but are hospitalised, i.e., subnormal cases.

Another point in which the present series differs from those in literature is the similarity of the average $\mathrm{pH}$ on different feeds. provided the children are accustomed to the feed. Marriott(7) remarks on the increased gastric secretion to meet the need when the child is kept on a high buffer feed, but does not think that complete cornpensation takes place. However, a study of Table III. would suggest that in a series of comparable cases the $\mathrm{pH}$ approximates closely regardless of the nature of the feed. The value of each feed expressed as ounces of cow's milk was worked out for all the artificially fed infants, but no connection between either the concentration or absolute quantity of protein and $\mathrm{pH}$ could be determined, provided the 
child had been on the same feed for some little time. A study of the titratable acidity that corresponds to the low $\mathrm{pH}$ values shows, what is obvious from theoretical considerations, the great increase in output of acid necessary to bring an artificial feed with a high buffer value to the same $\mathrm{pH}$ as a breast fed maximum (see Tables).

In the absolutely normal series there are not enough artificially fed cases to say whether the same would hold or not. However, the delay in obtaining the maximum will assumedly remain, as in no artificially fed infant was the maximum acidity found as early as one hour after feeding.

That it is the condition of the child rather than the nature of the feed that is of importance in determining the $\mathrm{pH}$ is indicated by observations on certain ill children who became progressively either better or worse while under observation. In those that went down hill, the acidity steadily decreased, while the converse occurred when the child made a steady recovery.

\section{Sick INFANTS.}

Vomiting children.

The series of children described shows the very high acidity associated with this condition. The cases were selected by one of us (D.P.) as being typical vomiters, though he was in complete ignorance of the values obtained (L.W.). One case, a female aged 2 months, suggests that these high acidities may be associated with pyloric spasm (cf. Parsons ${ }^{(8)}$ ), as the stomach was not empty at the end of three hours, and the titratable acidity was very high, $92 \% \mathrm{~N} / 10$ acid. It is not suggested that the acidity is the cause of the spasm; more likely it is the result (cf. adult cases). This was the only series of ill children examined that gave a high average maximum acidity. Davidsohn ${ }^{(3)}$, in his work on the child suffering from the exudative diathesis (symptoms mentioned, vomiting and diarrhœa) mentions the high values obtained (up to $2 \cdot 0$ ). Davison(4) states that vomiting increases the acidity.

Children suffering from infections, extreme degrees of marasmus, etc.

The figures agree with those of other authors. Marriott(7), Ylppö(9), etc., state that the gastric acidity is lowered. This is marked in bronchitis and similar infections though the eczema cases (all severe cases) actually gave a lower average acidity, and it is associated with increased mucus in the stomach contents. The curves of all feeds are not only lower but remarkably flattened (see Charts II., III., IV. and V.).

\section{Grneral Discussion.}

The study reported above indicates that gastric acidity in active healthy children, particularly in the breast fed, is such that active peptic digestion could take place. Free hydrochloric acid which corresponds to an acidity at 
which peptic activity is at its maximum is frequently present at some stage of digestion: this is in agreement with Parsons'( ${ }^{(8)}$ findings in marasmic children. The average $\mathrm{pH}$ is lower, i.e., acidity is greater, than is normally taught, if conclusions can be drawn from so few cases. Artificial feeding causes a delay in the maximum rise, apparently even when the buffer value of feed is approximately that of breast milk ( 1 part of milk to 2 of water). If the group of subnormal cases is considered, it is seen that compensation takes place to a very marked degree, so that, whatever the feed, the average maximum $\mathrm{pH}$ is the same. Similarly, the lowering of gastric acidity that takes place in ill children, except in uncomplicated cases of vomiting, is a general process and not related to one particular food. In fact, in infants as in adults, high and low acidity seem more closely related to the general condition (high acidity and good activity, low acidity and poor activity) than with the type of food or disease.

Note on the clinical application of results.

The striking difference in emptying time shown by breast fed and artificially fed infants is of significance in regard to the question of spacing infants' feeds. The stomach of a breast fed child is generally empty in $1 \frac{1}{2}$ hours: three-hourly feeds would, therefore, insure adequate emptying and opportunity for rest in such infants. However, in the artificially fed. whatever the nature of the feed, the stomach is not empty for two hours or more after feeding: hence, to insure complete emptying and a certain amount of gastric rest, a longer interval is necessary. Four-hourly feeds would, therefore, appear more rational (other things being equal) in the artificially fed child than in the infant on the breast.

Seven cases of persistent vomiting have been reported above; in all definite hyperacidity was demonstrated. The type of child investigated is one who, almost from birth, tends to vomit persistently. There may be no loss of weight, provided that an adequate amount of food is offered. Obstinate constipation is not present and diarrhœa is not the rule, which excludes pyloric stenosis on the one hand, and gastro-enteritis on the other. The vomit is sour with large curds and appreciable quantities may be returned. This type of case corresponds closely to that described by certain clinicians as " pyloric spasm." and they must be distinguished from cases of vomiting due to air swallowing caused by bad feeding. Clinically, they have been found to do best on small concentrated thickened feeds. It may be that the success of this therapy is partly due to the high buffer, i.e., high percentage of protein of the feed, but more likely is due to the mechanical effect of the thickened feed. Since in most vomiting children the feed is lessened or weakened, the recognition of this type of case is of great practical importance.

Children suffering from an infection, or seriously ill, have been shown to have a low gastric acidity. Whatever feed these children are given, they seem quite unable to raise their gastric acidity to that point at which peptic 
digestion is appreciable. This appears to us to be a very definite indication for acid feeds in such conditions. The addition of lactic. or hydrochloric. acid to the milk brings the stomach contents up to an acidity where peptivdigestion can take place. Peptonising the milk would also circumvent this, but has not proved so practicable.

\section{Summary.}

1. Normal healthy infants under one year have an average maximum gastric acidity of $\mathrm{pH} 3.02$ for all feeds. Breast fed infants have a higher acidity, i.e., 2.7, and in most cases those over one month old show free hydrochloric acid at some time during digestion.

2. The $\mathrm{pH}$ of 2.7 is such that active peptic digestion could take place:

3. The gastric emptying time in breast fed infants is more rapid than in the artificially fed.

4. Slightly underweight children have a lower acidity than true normals, though there is no obvious gastric defect. The average $\mathrm{pH}$ is nearly the same for the different feeds, indicating a compensatory increased gastric secretion, where infants arefed on high buffer feeds.

5. Infants suffering from persistent vomiting (not ruminators) have a high gastric acidity.

6. Ill children have a lowered gastric acidity.

7. The gastric findings in infants, as in adults, seem more closely associated with the general condition of the child than with any particular feed or disease.

We are indebted to Dr. Fric Pritchard, Director of the Hospital, for permission to work in the Research Laboratory and to the Medical Research Council which paid the expenses of this work.

\section{REFERENCES.}

1. Babbott, F. L., Johnston, J. A., Haskins, C. H., and Shohl, A. T., Am. J. Dis. Ch., Chicago, 1923, XXVI, 475-486.

2. Clark, W. M., The Determination of Hydrogen Ions, Baltimore, 1922, 99.

3. Davidsohn H., Arch. f. Kinderheilk, Stuttg., 1921, LXIX, 142 and 239.

4. Davison, W. C., Am. J. Dis. Ch., Chicago, 1925, XXX, 22.

5. Kronenberg, R., Jahrb. fur. Kinderheilk, Berlin, 1915, LXXXII, 401.

6. Levy, R. L., Rowntree, L. G., and Marriott, W. McK., Arch. Int. Med., Chicago, 1915, XVI, $38 \overline{9}$.

7. Marriott, W. McK., and Davidson, L. T., Am. J. Dis. Ch., Chicago, 1923, XXVI, 542.

8. Parsons, L., Lancet, 1924, I, 797.

a. Ylp̧nö, A., Acta Pediatrica, Stockholm, 1924, IIJ, $1 \curvearrowleft$ ! 